\title{
RELEVANSI RELIGIUSITAS DENGAN PERILAKU KONSUMSI
}

\author{
Desi Isnaini \\ IAIN Bengkulu \\ E-mail: desiisnaini@gmail.com
}

\begin{abstract}
Religiosity in every researchs admitted has related with economic behaviour. Wich related to others or personally. This research discuss about the relevance of religiosity to consumption behaviour, using library research. From this research can be concluded that religiosity will affect consumption behaviour, one of them is consumer behaviour. The more religiosity, then the consumption behaviour applied is the more advantages and the good consumption behaviour.
\end{abstract}

Keywords: Religiosity, behaviour, consumption

Abstrak: Religiusitas dalam bebabagi penelitian diakui mempunyai hubungan dengan perilaku perilaku ekonomi. Perilaku yang berdampak dengan pihak lain atau hanya secara pribadi. Penelitian ini membahas tentang relevansi religiusitas terhadap perilaku konsumsi dengan menggunakan studi pustaka. Dari penelitian ini dapat disimpulkan bahwa religiusitas seseorang akan mempengaruhi perilaku ekonomi salah satunya yaitu perilaku konsumen. semakin religius seseorang maka perilaku konsumsi yang di terapkan adalah perilaku konsumsi yang menjurus kepada hal kebaikan dan kemanfaatan.

Kata kunci: Religiusitas, Perilaku, Konsumsi

\section{A. PENDAHULUAN}

Agama berperan sangat vital dalam membentuk pribadi yang bersedia melakukan self monitoring guna intropeksi atas perbuatan yang telah maupun yang belum dilakukan sebagai batasan. Sikap pemantauan diri tersebut terbentuk dari perasaan bahwa setiap apa yang dilakukannya ada yang melihat dan memantau setiap tindakan yang dilakukan yaitu Allah yang maha melihat atas segala yang dilakukan mahluknya. Self monitoring ini akan menimbulkan self control yang kuat dan akan berdampak kepada perilaku yang baik, benar dan tidak menyimpang baik secara aturan pemerintah dan syariat.

Seseorang yang kuat keimanannya yakin bahwa Allah pasti mengawasi semua prilakau hambanya, maka ia akan selalu hati-hati dalam melakukan suatu perbuatan. Perlunya pengawasan dari diri sendiri ini terbangun dari keimanan seseorang kepada Allah SWT.1 Sikap religiusitas tidak hanya di wujudkan dalam praktek ibadah ritual semata tetapi pada aktivitas-aktivitas lain dalam kehidupan. Dalam dimensi agama, Islam mendorong kepada para pemeluknya untuk beragama secara penuh(kaffah) baik dalam berfikir dan bertindak harus di sandarkan kepada pengabdian dan penyerahan diri kepada Allah. Dalam aktivitas kehidupan sifat-sifat ini dapat di ambil dari sifat-sifat Nabi Muhammad SAW seperti jujur, adil, amanah, serta perilaku lainnya yang kita ikuti sebagai suri tauladandalam berbagai hal.

Perlunya pengawasan dari diri sendiri ini terbangun dari keimanan seseorang kepada Allah SWT, tidak ada aktifitas yang tidak diketahui oleh Allah yang maha melihat. Jika seseorang tidak mengabaikan hal tersebut maka setiap gerak dan tingkah lakunya tidak akan

\footnotetext{
${ }^{1}$ Ma'ruf Abdullah, Manajemen berbasis syariah, (Yogyakarta:Aswaja Pressindo, 2013), hlm. 305.
} 
keluar dari aturan dan batasan yang di tetapkan, hal ini sering diabaikan karena manusia pada saat itu lebih condong kepada keinginannya yang berorientasi kepada duniawi, lebih mengedepankan kepentingan semata-mata hanya untuk duniawi sering sekali berbenturan dengan aturan ajaran agama Islam.

Mencari keuntungan dengan jalan yang di larang oleh agama seperti mencuri, menipu dan lain sebagainya adalah hal yang jelas-jelas dilarang oleh agama. Kepentingan duniawi memang tidak bisa di hindari atau di hilangkan, namun jika kepentingan atau kebutuhan tersebut tetap di sandarkan kepada aturan agama maka yang didapat adalah suatu keberkahan bukan kesenangan semata. Sumber daya insani dalam ajaran agama di perintahkan untuk memenuhi kebutuhannya, menciptakan budaya etos kerja dan lain sebagainya dengan tidak melanggar aturan syariah.

Seseorang yang selalu mengaplikasikan keimanannya dengan sepenuhnya pasti akan mempertimbangkan atas perilaku atau tindakan yang di lakukannya baik itu terkait secara hubungannnya dengan Allah (hablumminallah) maupun dengan manusia lainnya (hablumminannas). Peran agama dapat mempengaruhi sikap individu, termasuk didalam bersikap terhadap pelaporan keuangan usaha

Sumber daya insani yang unggul adalah pribadi yang bisa mengorganisasi, mengimplementasi, mengevalusi, dan mengendalikan segala yang berada di bawah tanggung jawabnya. Yaitu dengan mempertimbangkan beberapa aspek yang berkaitan dengan rasionalitas, emosionalitas, dan spiritualitas. Unggul dalam hal praktek ekonomi maupun keimanan.

Aspek yang perlu diperhatikan untuk menjadi sumber daya insani yang unggul adalah aspek ketauhidan. Tauhid berasal dari bahasa Arab, yaitu kata بقوة yang artinya adalah megikat atau mengadakan perjanjian. Al-'aqdu berarti ikatan. At-tautsiiqu yang berarti kepercayaan atau keyakinan yang kuat. Tauhid adalah iman yang teguh, yang tidak ada keraguan sedikitpun bagi orang yang meyakininya. ${ }^{2}$

Tauhid adalah landasan utama yang menjadi fondasi dasar dalam segala hal. Tauhid dapat diibaratkan seperti tiang jembatan layang yang menancap ke bumi untuk menahan setiap beban yang ada pada jembatan tersebut. Tauhid berdasarkan kepada Al-Qur'an dan Hadis, sehingga setiap individu yang mengimani Al-Qur'an dan Hadis secara kaffah, maka ia akan menjadi sumber daya insani yang memiliki iman yang kokoh. Oleh sebab itu secara pribadi setiap mahluk harus tetap memelihara keiamanannya agar tidak melanggar syariat Allah. penanaman tauhid kepada diri sebagai pelaku ekonomi sangat di perlukan agar setiap perilaku yang dilakukan merujuk kepada hal kebaikann dan keberkahan.

Tauhid adalah keyakinan bahwa hanya Allah yang berhak disembah, diikuti, diharapkan, dan kepada takdir-Nya segala hal dikembalikan. Dengan tauhid inilah yang akan membuat seorang sumber daya insani yang beriman merasakan keamanan dan ketentraman dalam melakukan setiap aktivitasnya. Allah SWT berfirman dalam Al-Qur'an:

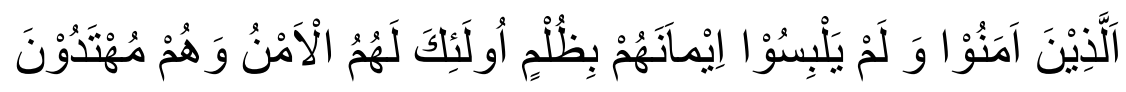

${ }^{2} \mathrm{Abu}$ Fahmi, dkk, HRD Syari'ah Teori Dan Implementasi Manajemen Sumber Daya Manusia Berbasis Syari'ah. (Jakarta: Gramedia Pustaka Utama, 2014), hlm.10. 
Artinya: Orang-orang yang beriman dan tidak mencampuradukkan iman mereka dengan kezaliman (syirik), mereka Itulah yang mendapat keamanan dan mereka itu adalah orang-orang yang mendapat petunjuk.(QS. Al-an'am:82)

Seseorang tidak cukup dengan mempertimbangkan aspek rasional dan emosional saja, ketika berhadapan dengan segala permasalahan yang dihadapinya. Lebih dari itu, aspek spiritualitas merupakan bentuk pengapdian seseorang kepada Tuhannya, dalam bentuk hablun minallah dengan cara menjalin hubungan yang baik dengan para manusia (hablun minannas). Saat seseorang mempertimbangkan tiga hal tersebut maka seseorang akan mendapatkan keuntungan yang berlipat ganda, atau dalam ekonomi Islam biasa disebut falah, yaitu keuntungan di dunia dan akhirat. ${ }^{3}$

Seseorang dalam menjalankan aktifitas maupun tindakannya dalam keseharian akan dipengaruhi oleh iman yang ada dalam dirinya. Dengan pengaruh iman, pengetahuan dan tindakan, proses perkrmbangan diri dibimbing menuju tujuan tertinggi yaitu pencapaian falah. Dalam diri manusia secara umum ada tingkatan perkembangan yaitu amarah (sifat kebinatangan), lawwamah (kemanusiaan) dan muthmainnah (ketuhanan,religius). ${ }^{4}$

Tingkatan terendah cenderung kepada keinginan diri secara rasional dan mungkin membawa manusia pada hal-hal yang rendah, menjadi egois, dan matrealistis. Pada hal ini diri tidak mampu mengidentifikasi apakah keputusan atau tindakan itu salah atau benar. Diri pribadi langsung mengambil sikap dengan menuruti nafsunya tanpa lagi memikirkan, mengevaluasi dan mempertimbangkannya berdasarkan nilai agama.

Tingkatan berikutnya yang lebih tinggi, diri mulai menyadari, mengasimilasi dan menerapkan nilai-nilai dengan mempertimbangkan nilai-nilai agama namun terkadang masih berprilaku secara irasionalatau rasional, untuk menerapkan nilai-nilai tersebut secara penuh maupun sebagian. Sumber daya insani untuk bertindak secara amoral atau moral, dalam hal ini diri menghadapi pilihan untuk mengikuti nafsunya atau sifat yang baik dan shaleh.

Manusia memiliki kapabilitas kuat untuk mengendalikan setiap situasi dan memposisikan diri secara benar, secara moral dan religius dalamm posisi yang baik. Dengan hal tersebut diri akan selalu menentukan pilihan terhadap prilaku yang akan di lakukan dengan berlandaskan aturan dan nilai-nilai agama secara benar. Manusia tersebut harus menyadari bahwa diri harus selalu mendekatkan kepada Tuhan dan hal ini adalah suatu proses dari diri seseorang dengan berusaha secara keras menjadi diri yang religius dimana setiap tindakan dan perilakunya adalah nilai-niliai kebenaran. Iman adalah landasan utama bagi tindakan sehari-hari setiap muslim, semakin baik tingkat iman yang dimiliki seseorang maka akan akan baik juga dalam perilakunya.

Religiusitas diri seorang muslim bisa di dapat dari mempelajari dan mempedomani Al-Quran dan Hadis, mengikuti kajian-kajian keagamaan, meningkatkan takwa kepada Allah yaitu dengan berusaha menjalankan hal-hal yang di perintahkan dan menjauhi laranganlaranganNya, jika ibadahnya baik maka akan berefleksi kepada perilakunya. Peranan religiusitas terhadap berbagai perilaku manusia sangat berpengaruh seperti perilaku konsumsi seseorang guna memenuhi kebutuhan, manfaat dan atau malah akan cenderung kepada hal

${ }^{3}$ Ika Yunia dan Abdul Kadir Riyadi, Prinsip Dasar Ekonomi Islam Perspektif Maqashid al-Syari'ah, (Jakarta: Kencana Prenadamedia Group), hlm. 288

${ }^{4}$ Iwan Triyuwono, Organisasi dan Akuntansi Syari'ah, (Yogyakarta: LKIS, 2000), hlm. 62. 
yang tidak baik.

\section{B. METODE PENELITIAN}

Penelitian ini menggunakan metode studi pustaka (library research) dengan menggunakan kajian-kajian litelatur yang membahas tentang religiusitas, perilaku konsumsi. Peneliti juga mengkaji tentang masalah di lapangan dan lingkungan sekitar guna memperkuat isi dari penelitian yang di angkat. Dari penelitian dan litelatur yang sudah kemudian akan di kaji dan di tarik suatu kesimpulan.

\section{HASIL DAN PEMBAHASAN}

Religiusitas merupakan sesuatu hal yang menujukkan kualitas penghayatan dan sikap hidup seseorang berdasarkan nilai-nilai keagamaan yang menjadi keyakinannya. ${ }^{5}$ Nilai-nilai keagamaan akan cenderung menunjukkan kepada hal-hal kebaiikan. Terkait konsumsi dalam ekonomi setiap aktifitas ekonomi dalam hal ini adalah konsumsi maka, setiap konsumsi yang dilakukan akan bertitik kepada hal kebaikan dan kemanfaatan. Membedakan antara kebutuhan dan keinginan. Meniggalkan perilaku yang cenderung kapada hal keburukan seperti hedonis dan boros.

Religiusitas juga diartikan sebagai keterkaitan individu secara penuh kepada tuhan sebagai sang pencita yang di internalisasikan dalam diri individu dan dimanifestasikan dalam perilaku keseharian. ${ }^{6}$ Seseorang yang religius akan tergambarkan dari segi perilaku, motivasi dalam melakukan setiap aktifitasnya. Aturan dan pedoman-pedoman agama (religion) menjadi landasan dalam melakukan suatu tindakan yang mendatangkan kebaikan. Setiap orang yang tidak memiliki aturan atau pedoman terutama terkait aturan agama maka kehidupannya akan sulit terkontrol dan mudah terpengaruh melakukan kegiatan yang melanggar syariat dan menjurus kepada hal-hal yang merugikan. Perilaku konsumsi dengan mengedepankan keinginan dan kesenangan semata akan memicu seseoarang melakukan tindakan yang malah akan berdampak negatif baik secara pribadi dan bisa juga ke orang lain. Terdapat 5 dimensi dalam religiusitas yaitu: ${ }^{7}$

1. Religious belief, adalah tingkat sejauh mana seseorang menerima hal-hal yang dogmatis dalam agamanya. Seperti dalam perwujudan dua kalimat syahadat.

2. Religious Practice, yaitu tingkatan sejauh mana seseorang mengerjakan kewajibankewajibannya dalam ritual agamanya seperti sholat, puasa dan praktek muamalah lainnya

3. Religious feeling, yaitu merasakan kedekatan-kedekatan dengan Allah, bertawakal, khusuk dalam beribadah, perasaan bersyukur dan perasaan lainnya yang mencirikan kedekatan dengan Allah.

4. Religious knowledge, yaitu dimensi yang menerangkan seberapa jauh seseorang mengetahui ajaran-ajaran agamanya terutama yang ada dalam kitab sucinya.

5. Religious effect, yaitu dimensi yang mengukur sejauh mana perilaku seseorang di motivasii

\footnotetext{
${ }^{5}$ Ima Amaliah dkk, "Relevansi Nilai Religiusitas Islam Dalam Berkonsumsi Dengan Kebahagiaan", Prosiding SNaPP2015 Sosial Ekonomi dan Humaniora, 2015

${ }^{6}$ Ma'zumi dkk, "Pengaruh Religiusitas Terhadap Perilaku Ekonomi Masyarakat Pasar Tradisional", Jurnal Al-Qalam, Vol. XXXIV No. 02, 2017, hlm. 288

${ }^{7}$ Eka Yanuarti, "Pengaruh Sikap Religiusitas Terhadap Perilaku Hidup Bersih dan Sehat Masyarakat Kabupaten Rejang Lebong”, Jurnal Kajian KeIslaman dan Kemasyarakatan, hlm. 24
} 
oleh ajaran-ajaran agamanya dalam kehidupan sosial, misalnya mendemawankan hartanya, mengunjungi orang yang sakit, menolong orang lain dan tindakan-tindakan lain yang terwujud dari suatu nilai-nilai agama yang tertanam dalam diri yang tergambarkan dalam suatu perilaku.

Perilaku konsumsi dalam hal ini menurut penulis termasuk kedalam religious effect, dimana perilaku yang di wujudkan dalam suatu tindakan yang sudah merefleksikam nilai nilai agama (religion). Seseorang yang menjalankan agamanya secara kaffahakan melakukan suatu tidakan yang positif seperti dalam hal perilaku konsumsi. Perilaku konsumsi yang dilakukan adalah perilaku yang sejalan dengan nilai-nilai agama.

Kebahagiaan hanya akan dapat dirasakan manakala ia dapat melakukan aktifitas konsumsi mendasar pada nilai-nilai agama yang menjadi keyakinannya. Manusia tidak memperturutkan hawa nafsunya untuk memenuhi semua keinginannya. Manusia harus mampu memilah apa yang menjadi kebutuhan dan keinginan. ${ }^{8}$

Sesuatu yang menjadi keiginan belum tentu hal tersebut dalah sebuah kebutuhan. Namun setiap kebutuhan yang di penuhi sedikit banyaknya di dasari oleh keinginan. Kebutuhan akan berdampak pada perolehan manfaat sedangkan keinginan jika tidak terkontrol akan mendatangkan keburukan bagi orang yang mengkonsumsisnya. Ekonomi Islam juga mengenal berbagai tingkatan kebutuhan ekonomi yang dikenal dengan kebutuhan daruriyat, hajiyat dan tahsiniyat.

Setiap manusia harus mempunyai prinsip-prinsip yang berlandaskan kepada aturanaturan yang ada terlebih yang bersumber dari al-Qur'an dan Hadist yang menjadi pedoman utama setiap muslim.

Dalam prinsip ekonomi ada 5 nilai atau prinsip dalam perilaku konsumsi yaitu prinsip keadilan, prinsip kebersihan, prinsip kesederhanaan, prinsip kemurahan hati dan prinsip moralitas. ${ }^{9}$ Secara sederhana religiusitas dengan prinsip dasar perilaku konsumen dapat di gambarkan seperti berikut.

\section{Gambar 1. Religiusitas dan prilaku konsumen}

\begin{tabular}{|l|l|}
$\begin{array}{l}\text { a. Religious belief } \\
\text { b. Religious Practice } \\
\text { c. Religious feeling } \\
\text { d. Religious knowledge } \\
\text { e. Religious effect }\end{array}$
\end{tabular}$\longrightarrow \begin{aligned} & \text { a. Prinsip Keadilan } \\
& \text { b. Prinsip Kebersihan } \\
& \text { c. Prinsip kesederhanaan } \\
& \text { d. kemurahan hati } \\
& \text { e. prinsip moralitas }\end{aligned}$

Sumber: Yusuf Qardawi

Perilaku seseorang juga didorong oleh motif tertentu untuk melakukan suatu tindakan. Dengan kata lain perilaku muncul dari motif dalam diri seseorang yang di aplikasikan berupa tindakan. Motif yang positif bersumber dan dibatasi oleh hal-hal kebaikan.

\footnotetext{
${ }^{8}$ Ima Amaliah dkk, Relevansi Nilai..., hlm. 119

${ }^{9}$ Yusuf Qhardawi, Norma dan Etika Ekonomi Islam, (Jakarta: Gema Insani, 1997), hlm. 97
} 


\section{KESIMPULAN}

Religiusitas mempengaruhi perilaku konsumen. Setiap individu yang menjalankan ajaran dan aturan agama (religion) akan memperhatikan batasan-batasan konsumsi yang sesuai dengan tuntunan syariat. Semakin baik tingkatan nilai religiusitas seseorang maka akan semakin baik pula perilaku konsumsi yang di aplikasikan. Individu lebih mengedepankan kebutuhan daripada kesenangan. Kebutuhan akan berimbas pada kemanfaatan serta keinginan bisa saja belum menjadi kebutuhan dan malah bisa menjadi hal yang bukan suatu kebutuhan. Prinsip-prinsip perilaku konsumsi juga selalu harus di perhatikan dan di jalankan agar apa yang di konsumsi dan di gunakan nilai manfaatnya dapat di rasakan secara utuh.

\section{E. DAFTAR PUSTAKA}

Abdullah, Ma'ruf. 2013. Manajemen berbasis syariahI. Yogyakarta:Aswaja Pressindo.

Amaliah, Ima., dkk. 2015. "Relevansi Nilai Religiusitas Islam Dalam Berkonsumsi Dengan Kebahagiaan”. Prosiding. Sosial, Ekonomi, dan Humaniora. ISSN2089-3590 |EISSN 2303-2472

Fahmi, Abu., dkk. 2014. Hrd Syari'ah Teori Dan Implementasi Manajemen Sumber Daya Manusia Berbasis Syari'ah. Jakarta: Gramedia Pustaka Utama.

Ma'zumi dkk. 2017. "Pengaruh Religiusitas Terhadap Perilaku Ekonomi Masyarakat Pasar Tradisional". Jurnal Al-Qalam. Vol XXXIV No 02

Qhardawi, Yusuf. 1997. Norma dan Etika Ekonomi Islam. Jakarta: Gema Insani.

Triyuwono, Iwan. 2000. Organisasi Dan Akuntansi Syari'ah. Yogyakarta: LKIS.

Yanuarti, Eka. "Pengaruh Sikap Religiusitas Terhadap Perilaku Hidup Bersih Dan Sehat Masyarakat Kabupaten Rejang Lebong". jurnal kaian keisalaman dan kemasyarakatan, P3M STAIN Curup.

Yunia, Ika., Abdul Kadir Riyadi. Prinsip Dasar Ekonomi Islam perspektif maqashid alsyari'ah. Jakarta: Kencana Prenadamedia Group. 